\title{
Erratum to: Chapter 8, 9 and 10 of Rosa Luxemburg: A Permanent Challenge for Political Economy Judith Dellheim and Frieder Otto Wolf
}

\section{Erratum to:}

Chapter 8 in: Tove Soiland, A Feminist Approach to Primitive Accumulation, DOI 10.1057/978-1-137-60108-7_8

The reference "Boltanski, L., \& Chiapello, E. (2005a). Te new spirit of capitalism. London: Verso.” has been deleted.

The online version of the updated original chapter can be found under 10.1057/978-1-137-60108-7_8

\section{Erratum to:}

Chapter 9 in: Klaus Dörre, Limits to Landnahme. Growth Dilemma as Challenge, DOI 10.1057/978-1-137-60108-7_9

The reference is now updated as "Boltanski, L., \& Chiapello, E. (2007). The new spirit of capitalism. London and New York: Verso." 
The reference is now updated as "Boltanski, L., \& Chiapello, È. (2005). The role of criticism in the dynamics of capitalism: social criticism versus artistic criticism. In M. Miller (Ed.), Worlds of capitalism. Economic performance, governance and economic change in the era of globalization (pp. 237-266). London/New York: Routledge.

The online version of the updated original chapter can be found under 10.1057/978-1-137-60108-7_9

\section{Erratum to:}

Chapter 10 in: Michael Brie, A Critical Reception of Accumulation of Capital, DOI 10.1057/978-1-137-60108-7_10

The reference is now updated as "Boltanski, L., \& Chiapello, E. (2007). The new spirit of capitalism. London and New York: Verso."

The online version of the updated original chapter can be found under 10.1057/978-1-137-60108-7_10 